\title{
THE CONTENT OF RARE-EARTH ELEMENTS IN MOBILE-PHONE COMPONENTS
}

\section{VSEBNOST ELEMENTOV REDKIH ZEMELJ V KOMPONENTAH PRENOSNIH TELEFONOV}

\author{
Martin Smodiš ${ }^{1}$, Niko Samec ${ }^{1}$, Borut Kosec ${ }^{2}$, Črtomir Donik ${ }^{3}$, Matjaž Godec ${ }^{3}$, Rebeka Rudolf ${ }^{1}$ \\ ${ }^{1}$ University of Maribor, Faculty of Mechanical Engineering, Smetanova 17, 2000 Maribor, Slovenia \\ 2University of Ljubljana, Faculty of Natural Sciences and Engineering, Aškerčeva cesta 12, 1000 Ljubljana, Slovenia \\ ${ }^{3}$ Institute of Metals and Technology, Lepi pot 11, 1000 Ljubljana, Slovenia \\ martin.smodis@gmail.com
}

Prejem rokopisa - received: 2017-05-28; sprejem za objavo - accepted for publication: 2017-11-23

doi: $10.17222 /$ mit.2017.064 \begin{abstract}
In the present article, we present a study in which we want to establish whether it is possible to determine the presence and mass
fraction of rare-earth elements (REEs) in the components of discarded mobile phones. In order to do so, we have selected the following characterization techniques and microchemical analysis methods: Energy Dispersive Spectroscopy (EDS) and Wavelength Dispersive Spectroscopy (WDS). To confirm the hypothesis, we have randomly selected six models of mobile phones from different manufacturers, produced in the period 2004-2015. As representative samples of mobile phone components, we analysed the magnets (containing REEs (vibrator and speaker). To confirm the presence and determine the content of REEs in individual components of mobile phones, we used Light Microscopy (LM) and Scanning Electron Microscopy (SEM) in combination with microchemical analyses: Energy Dispersive Spectroscopy (EDS) and Wavelength Dispersive Spectroscopy (WDS). Our research has shown that the magnets consist of a magnetic core (which is composed of Fe-Nd-Pr and in newer mobile phones is also enriched with $\mathrm{Gd}$ ) and of a corrosion resistant coating with a thickness of 24-26 $\mu \mathrm{m}$. The latter is composed of three layers (Ni-Cu-Ni). With extensive microchemical analyses EDS and WDS on the surface of magnetic cores, we have established that the average content of REEs (Nd, Pr, Gd) in both magnets (vibrator and speaker) of a mobile phone is roughly
\end{abstract} $13.5 \%$ of mass fractions or $0.082 \mathrm{~g}$.

Keywords: mobile phones, components, rare-earth elements (REE), chemical structure, characterization, electron and optical microscopy, microchemical analysis

V prispevku prikazujemo raziskavo, s katero smo želeli ugotoviti, ali je na podlagi ustrezno izbranih tehnik karakterizacije in mikrokemičnih analiz možno določiti prisotnost in masni delež elementov redkih zemelj (ERZ) v sestavnih komponentah odsluženih prenosnih telefonov. Za potrditev hipoteze smo naključno izbrali šest modelov prenosnih telefonov različnih proizvajalcev, izdelanih v obdobju 2004-2015. Kot reprezentativne vzorce sestavnih komponent prenosnih telefonov smo analizirali magnete (vibrator in zvočnik), ki vsebujejo ERZ. Za potrditev prisotnosti in določitev vsebnosti ERZ v posameznih sestavnih komponentah prenosnih telefonov smo uporabili svetlobno (SM) in vrstično elektronsko mikroskopijo (SEM) v kombinaciji z mikrokemičnima analizama: energijsko disperzijsko spektroskopijo (EDS) in valovno disperzijsko spektroskopijo (WDS). Naše preiskave so pokazale, da so magneti sestavljeni iz magnetnega jedra, ki je sestavljeno iz Fe-Nd-Pr (NdFeB), v novejših prenosnih telefonih pa je obogateno tudi z Gd ter iz protikorozijske zaščitne prevleke z debelino 24-26 $\mu \mathrm{m}$, ki je sestavljena iz treh plasti (Ni-Cu-Ni). Z obširnimi mikrokemičnimi analizami EDS in WDS na površini magnetnih jeder je bilo ugotovljeno, da je povprečna vsebnost elementov redkih zemelj (Nd, Pr, Gd) približno 13,5 mas. \% oziroma 0,082 g skupno v obeh magnetih (vibratorja in zvočnika) mobilnega telefona.

Ključne besede: prenosni telefoni, komponente, elementi redkih zemelj (ERZ), kemijska sestava, karakterizacija, elektronska in optična mikroskopija, mikrokemična analiza

\section{INTRODUCTION}

Rare-earth elements (REEs) are becoming very useful materials, for they represent one of the most important components in advanced technologies, without which we cannot imagine the production of high-tech devices and further development of green technology/green energy programmes. The usefulness of REEs is related to their unique chemical/physical, catalytic, electrical, magnetic and optical properties. ${ }^{1-3}$

Their end uses can be can be grouped into two broad categories. In the first category, rare earths act as "process enablers', i.e., they are used in the production process but they are not actually contained in the end product. For instance, light rare earths are used in polishing powders $(15 \%)$ in the glass, electronics, and optics industries; they also serve as fluid-cracking catalysts $(13 \%)$ in refining and other chemical processes. In the second category, REEs act as 'product enablers' that give advanced materials unique properties that play a key role in the performance of high-tech products. REE-based permanent magnets are currently perhaps the most important of these product-enabling applications, as the addition of rare earths can boost the force of permanent magnets $(20 \%)$, which is usefully applied in products such as electric motors and turbines. Another key application pertains to REE phosphors (7\%) used in lighting and displays, enabling technologies such as compact fluorescent lamps and LCD screens. Other important uses are in batteries ( $8 \%$ ); in the coating of autocatalysts 
(6\%); and as additives in high-tech alloys (10\%), glass (7\%), and ceramics (5\%), etc. ${ }^{4-9}$ Great usability of REEs in advanced technologies, consequently, generates an extreme demand, which is the main issue in the domain of REE supply. The fact is that the European Union (EU) does not have enough REEs, therefore approximately $90 \%$ has to be imported, primarily from China. ${ }^{10}$ China has been a leading force in the REE market for the past 20 years and today it operates the global market with an $82.7 \%$ share. It is estimated ${ }^{4,5,9}$ that the demand for REEs will increase by $20 \%$ by 2018 and by 2020 by over $50 \%$. The global REE market has already crashed in the past, which led to the implementation of Chinese quotas in 2010/11. This led European geological surveys to intensify their data-collation efforts, and spurred companies, from both Europe and abroad, to do more independent exploration projects. However, most of them were not implemented in mining practice due to questionable economic viability of such procedures. ${ }^{9}$ Moreover, efforts in scientific research were intensified, namely in the domain of recycling procedures pertaining to REE recycling of waste products such as scrap electronics, predominantly carried out on a laboratory research level. ${ }^{11}$ The quantity of waste electrical and electronic equipment in the EU in relation to the rest of the world is increasing rapidly (by $3 \%$ to $5 \%$ on an annual basis). ${ }^{12}$ Thus, the EU Directive on Waste Electrical and Electronic Equipment (WEEE) ${ }^{13}$ was adopted in July 2003 and revised in 2012. It aims towards re-use, recycling and other forms of recovery of waste electrical and electronic equipment, ${ }^{14}$ which reduces the disposal of waste and contributes to the efficient use of resources and the retrieval of valuable secondary raw material. With this Directive ${ }^{13}$ minimum goals that apply to the processing and recycling of waste electrical and electronic equipment from the categories of Information Technology and Telecommunications were set. This also includes mobile phones, which are the subject of the present study.

According to the data, ${ }^{15}$ in Europe 160 million cell phones per year are discarded, sent to landfills and remain uncollected and unrecycled, which represents an annual material loss in the amount of 500 million US dollars. According to the analyses of the global market for mobile phones, ${ }^{16} 1917$ million mobile phones were released on the world market, 210.3 million of which were on the European one. Analysts estimated ${ }^{16}$ that in 2016, the amount of the global market of released mobile phones soared on average by $7 \%$, and consequently, in 2018 , over two billion will be released on the world market. The amount of WEEE will grow correspondingly, causing significant adverse effects on the environment. A possible solution to this problem might be the recycling of discarded mobile phones along with the recovery of valuable secondary raw material and REEs from their constituent components. Recycling a million cell phones results in obtaining $9.000 \mathrm{~kg} \mathrm{Cu}, \mathrm{Ag}$
$250 \mathrm{~kg}, 24 \mathrm{~kg}$ and $9 \mathrm{~kg}$ of $\mathrm{Au}$ and $\mathrm{Pd}$, and a certain amount of REEs. ${ }^{11}$ We should not ignore the fact that getting metals with modern recycling processes is 2 to 10 times more energy efficient than smelting metals from mineral ores. Recycling also generates a smaller percentage of $\mathrm{CO}_{2}$ emissions and has significant benefits compared to mining in terms of land use and hazardous emissions. For REEs, the specific emissions avoided by state-of-the-art recycling are reported as being even higher. ${ }^{9}$ REE recycling would also provide significant benefits with respect to groundwater protection, acidification, eutrophication, and climate protection. This report also states that the recycling of REEs will not involve radioactive impurities, as is the case with primary production. ${ }^{5}$

Notwithstanding the economic viability of recycling discarded mobile phones, we are bound by the European Directive on WEEE to implement rapid recycling and thereby reducing the disposal of WEEE, and increasing resource efficiency and the recovery of valuable secondary raw material from discarded mobile phones.

In sum, on the one hand there is an extreme demand for REEs due to the highly versatile use in advanced technologies, with European high-tech industry being completely dependent on their availability on the global market. On the other hand, we have a year-on-year growth in the production of high-tech electrical and electronic devices with a consequent rise in the quantities of WEEE and their uncontrolled deposition in the environment, which has an increasingly negative impact on the environment. Due to the still insufficiently regulated domain of regaining REEs and secondary raw material from WEEE, there are major energy, raw material and financial losses, causing an unnecessary burden on the environment. The solution to this problem might be the accelerated multi-element recycling of WEEE, including REE in discarded mobile phones treated in the present study. Based on the above, the main purpose of the study is to determine the content of REEs in the constituent components of discarded mobile phones.

\section{EXPERIMENTAL PART}

For the study, six different models of discarded mobile phones from different manufacturers, manufactured in the period 2004-2015, were selected at random. Every mobile phone was stripped down to basic functional components: the electronic circuit, microphone, speaker, vibrator, camera, display, battery, etc. In the first phase of the experimental work, we performed a process of identifying mobile phone components which could contain REE. By doing so, we wanted to determine whether several different REE are present in the key components and what their contents are (in mass fractions, $w / \%$ ). Based on a review of specialist literature ("state-of-theart"), we decided to limit the selection to two representative samples of the constituent components (a vibrator 


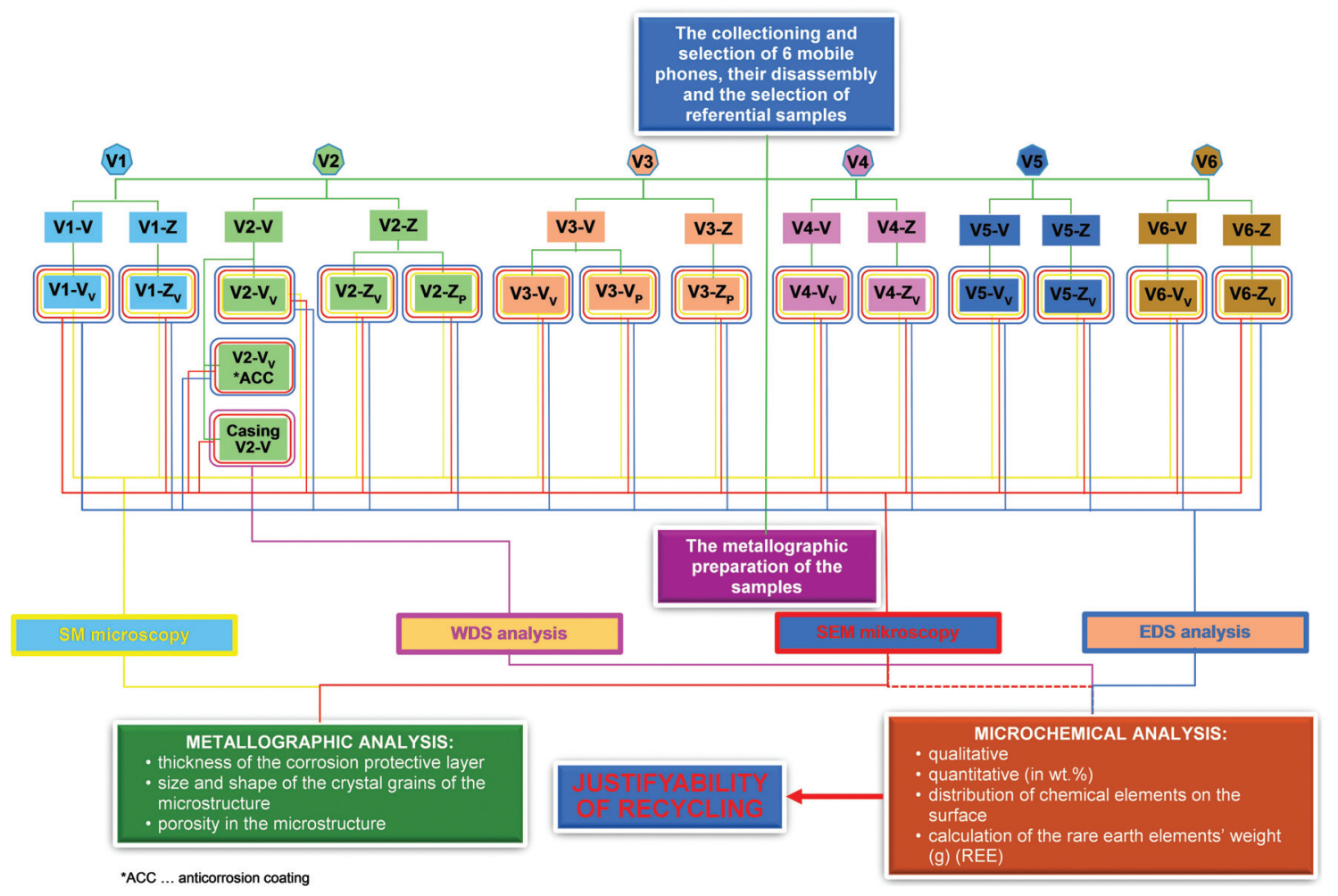

Figure 1: Schematic representation of the experimental work carried out

and a speaker) of discarded mobile phones, for which we assumed, based on a literature review, ${ }^{9,17}$ that their constituent components are made of magnetic materials, in which, with the proper technique of characterization and analytical techniques, we could identify the presence of REEs and determine their content. The scheme of the identification process carried-out is shown in Figure 1.

Before conducting the study, we selected relevant components, recorded and tagged them, extracted magnet samples, documented and tagged them appropriately (Figure 2) and weighed them on a digital laboratory scales. $^{18}$ An overview of representative samples of magnets for their characterization with LM and SEM microscopy and EDS and WDS analysis is presented in Table 1.

Table 1: Overview of representative samples of magnets for the characterization of the LM and SEM microscopy

\begin{tabular}{|c|c|c|c|c|c|}
\hline \multirow{2}{*}{$\begin{array}{l}\text { Tag of the } \\
\text { selected } \\
\text { mobile } \\
\text { phone }\end{array}$} & \multirow{2}{*}{$\begin{array}{c}\text { Year of } \\
\text { production } \\
\text { of a } \\
\text { mobile } \\
\text { phone }\end{array}$} & \multicolumn{2}{|c|}{$\begin{array}{c}\text { Tag of representative samples of } \\
\text { magnets } \\
\text { V - vibrator or Z - speaker }\end{array}$} & \multicolumn{2}{|c|}{$\begin{array}{l}\text { The weight of a } \\
\text { representative sample } \\
\text { of the magnet }(\mathrm{g})\end{array}$} \\
\hline & & $\begin{array}{c}\mathrm{Z}_{\mathrm{v}}-\text { speaker/ } \\
\text { longitudinal } \\
\text { section } \\
\mathrm{Z}_{\mathrm{p}} \text { - speaker/ } \\
\text { cross section }\end{array}$ & $\begin{array}{c}\mathrm{V}_{\mathrm{v}}-\text { vibrator/ } \\
\text { longitudinal } \\
\text { section } \\
\mathrm{V}_{\mathrm{p}} \text { - vibrator/ } \\
\text { cross section }\end{array}$ & $\begin{array}{c}\mathrm{Z} \\
\text { (speaker) }\end{array}$ & $\underset{\text { (vibrator) }}{\mathrm{V}}$ \\
\hline V1 & 2015 & $\mathrm{~V} 1-\mathrm{Z}_{\mathrm{V}}$ & $\mathrm{V} 1-\mathrm{V}_{\mathrm{V}}$ & 0.354 & 0.148 \\
\hline $\mathrm{V} 2$ & 2008 & $\begin{array}{l}V 2-Z_{V} \\
V 2-Z_{P}\end{array}$ & $V 2-V_{V}$ & 0.202 & 0.395 \\
\hline V3 & 2007 & $\mathrm{~V} 3-\mathrm{Z}_{\mathrm{V}}$ & $\begin{array}{l}V 3-V_{V} \\
V 3-V_{P}\end{array}$ & 0.416 & 0.259 \\
\hline V4 & 2004 & $\mathrm{~V} 4-\mathrm{Z}_{\mathrm{V}}$ & $\mathrm{V} 4-\mathrm{V}_{\mathrm{V}}$ & 0.603 & 0.231 \\
\hline V5 & 2008 & $\mathrm{~V} 5-\mathrm{Z}_{\mathrm{V}}$ & $\mathrm{V} 5-\mathrm{V}_{\mathrm{v}}$ & 0.473 & 0.440 \\
\hline V6 & 2006 & V6-Z $Z_{V}$ & V6- $V_{V}$ & 0.069 & 0.071 \\
\hline
\end{tabular}

For the purpose of LM microscopy, we used an optical metallurgical microscope Nikon Epiphot 300 that allowed magnification up to 1,000 times and implemented digital photography and image analysis using Olympus AnalxSIS 3.2. software. Samples of LM microscopy were properly treated with a conventional metallographic procedure. The surface of magnet samples $\mathrm{V} 2-\mathrm{Zp}$ and $\mathrm{V} 3-\mathrm{Vp}$ was examined transversely, while the surface of magnet samples $V 1-\mathrm{V}_{\mathrm{V}}, \mathrm{V} 1-\mathrm{Z}_{\mathrm{V}}, \mathrm{V} 2-\mathrm{V}_{\mathrm{V}}$, V3- $\mathrm{V}_{\mathrm{V}}, \mathrm{V} 3-\mathrm{Z}_{\mathrm{v}}, \mathrm{V} 4-\mathrm{V}_{\mathrm{v}}, \mathrm{V} 4-\mathrm{Z}_{\mathrm{v}}, \mathrm{V} 5-\mathrm{VV}, \mathrm{V} 5-\mathrm{Z}_{\mathrm{v}}, \mathrm{V} 6-\mathrm{V}_{\mathrm{V}}$ and $\mathrm{V} 6-\mathrm{Z}_{\mathrm{V}}$ was examined longitudinaly. ${ }^{18}$ For the samples of magnets that were taken transversely, the purpose was to identify the thickness of individual layers of the corrosion-protective coating, while the purpose of longitudinally examined magnet samples was to get the integral impression of the microstructure of their cores. For each magnet sample, six LM images of the microstructure of their surfaces at different magnifications were captured and analysed. Those LM images served as the basis for the quantitative metallographic analysis. The grain size and percentage of porosity in the microstructure of the magnetic cores were determined with the $\mathrm{ASTM}^{19}$ planar analysis method with the assumption that the crystal grains are square-shaped.

An in-depth examination of the microstructure was performed with the SEM microscope JEOL JSM 5610 with the EDS IXRF SYSTEM, Inc. 500 Digital Processing analytical technique as well as with the SEM microscope Sirion $400 \mathrm{NC}$ with the EDS Oxford INCA 350 analytical technique. For examination purposes, the magnet samples were thoroughly polished. By doing so, 
we removed the reaction products generated by the chemical etching preparation. Thus, we ensured the surfaces of representative samples had an identical starting point. In the first part, we tested the chemical composition and the presence of REEs on the exterior of the vibrator by means of WDS analysis. The analysis parameters were: an accelerating voltage of $20 \mathrm{kV}$, current of $60 \mathrm{nA}$ and signal accumulation time of $15 \mathrm{~s}$. We chose the LiF crystal for the analysis, as it is the most suitable one for the applied wavelengths. For characterization with SEM microscopy, the following setup parameters were applied: an accelerating voltage of $20 \mathrm{kV}$, various magnifications 35-, 1,500-, 1,700- and 2,500-times in correlation to the EDS analysis, a working distance of $20 \mathrm{~mm}$ from the sample and an average time of signal accumulation of 100-120 s.

The magnet sample of the vibrator $\mathrm{V} 2-\mathrm{V}_{\mathrm{V}}$ was examined without prior removal of the corrosion-protective coatings. On samples $\mathrm{V} 2-\mathrm{Z}_{\mathrm{P}}, \mathrm{V} 3-\mathrm{V}_{\mathrm{P}}$ anticorrosion coating on the transverse surface was examined, while the magnet samples $\mathrm{V} 1-\mathrm{V}_{\mathrm{V}}, \mathrm{V} 1-\mathrm{ZV}, \mathrm{V} 2-\mathrm{V}_{\mathrm{V}}, \mathrm{V} 3-\mathrm{V}_{\mathrm{V}}$, $\mathrm{V} 3-\mathrm{Z}_{\mathrm{V}}, \mathrm{V} 4-\mathrm{V}_{\mathrm{V}}, \mathrm{V} 4-\mathrm{Z}_{\mathrm{V}}, \mathrm{V} 5-\mathrm{V}_{\mathrm{V}}, \mathrm{V} 5-\mathrm{Z}_{\mathrm{V}}, \mathrm{V} 6-\mathrm{V}_{\mathrm{V}}$ and $\mathrm{V} 6-\mathrm{Z}_{\mathrm{V}}$ were examined on the longitudinal surface after removing the anti-corrosion protection layer. ${ }^{18}$

\section{RESULTS AND DISCUSSION}

The research work limitations were: the constantly changing technology of mobile phone manufacturing, the large number of manufacturers, many different models of mobile phones; for the research it was necessary to disassemble mobile phones down to their basic components, the examined representative samples (vibrator and speaker) were magnetic and very small in dimensions. The magnetism of the samples interfered with the focused beam of electrons in the scanning electron microscope, which reflected in the distortion and reduced resolution of the electronic image, whereas the magnetism had a negligible effect on the conduct of the microchemical analysis. We conducted the study with the presumption that we have ensured the appropriate systematic method of collection of discarded mobile phones and that we included representative samples. Our assumption for the quantitative microstructural analysis, based on the carried-out microchemical analyses, was that the microstructure of the samples' magnetic cores is sintered and homogeneous by volume in its chemical composition, that the rudimentary crystal grains are sintered microstructures of the magnetic core and square-shaped, and that the porosity is in most cases visible as dark areas, which are uncovered during the microstructural examination of the etched surface of the samples' magnetic cores with an optical microscope.

The study was limited to the LM and SEM characterization techniques, which allow us insight into the microstructure (size and shape of the crystal grains, porosity, thickness of individual layers of protective coating) of the representative samples of the two main components (the vibrator and speaker) of discarded mobile phones. In addition, we used semi-quantitative EDS and WDS microchemical analyses. These analytical methods have enabled us to determine the presence and content of REE in selected samples of the constituent components of discarded mobile phones and their distribution over the surface of the sample. Due to the complexity and the time-and-money-consuming nature of the WDS analysis, we conducted a test for the presence of REEs only on one of the vibrator sample's exterior (V2-V). Given that we primarily were looking for the presence of REEs, we conducted an analysis without applying the aforementioned standards.

\subsection{Microstructural analysis}

The anti-corrosion coating of the sample V3- $\mathrm{V}_{\mathrm{P}}$ 's magnet is shown in Figure 3a, where, in the upper part of the cross-sectional area, the anti-corrosion coating with the estimated thickness d) of $24.38 \mu \mathrm{m}$ is clearly visible, and consists of three layers. The estimated thickness of the upper layer a) is $9.03 \mu \mathrm{m}$, the central layer b) $7.81 \mu \mathrm{m}$ and the lower layer c) $7.54 \mu \mathrm{m}$. The microstructure of the sample in the magnetic core of the vibrator $\left(\mathrm{V} 3-\mathrm{V}_{\mathrm{V}}\right)$ is shown in Figure $\mathbf{3 b}$ and is typical of a sintered state; crystal grains are mainly polygonal in shape, irregular rounded crystal grains are also partly present. Our calculations have shown that the crystal grains are on average $5.4 \mu \mathrm{m}$ in size and that the porosity percentage is less than $1 \%$.

The loudspeaker's magnetic core sample $\left(\mathrm{V} 3-\mathrm{V}_{\mathrm{Z}}\right)$ microstructure is shown in Figure 3c, from which it is apparent that it is typical for a sintered state; crystal grains are mainly of polygonal shape, but also of irregu-

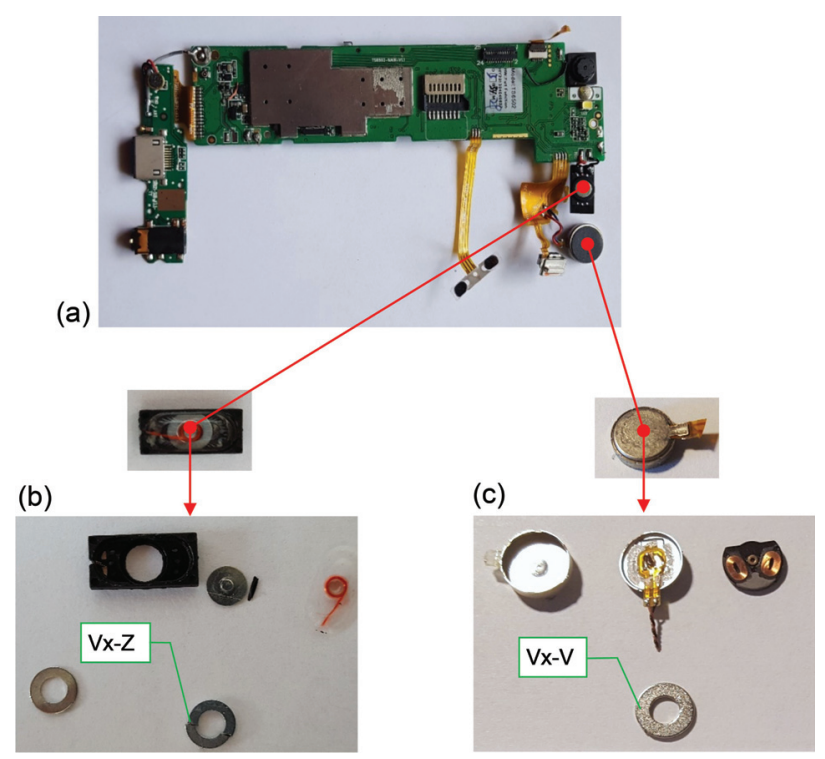

Figure 2: Display case of an exhibited disused mobile phone: a) An electronic circuit with a speaker and a vibrator, b) Exhibited speaker with the sample of the magnet $\left(\mathrm{V}_{\mathrm{X}}-\mathrm{Z}\right)$, c) Exhibited vibrator with the sample of the magnet $\left(\mathrm{V}_{\mathrm{X}}-\mathrm{V}\right)$ 
lar curved shape. Furthermore, calculations have shown that crystal grains are, on average, $6.7 \mu \mathrm{m}$ in size and that the porosity percentage is less than $1 \%$.

Table 2: Characteristics of representative samples of the magnets: a) the thickness of each layer of the corrosion protective coating, b) the grain size of the magnetic core

\begin{tabular}{|c|c|c|c|c|}
\hline \multirow{2}{*}{$\begin{array}{c}\text { Representative } \\
\text { sample of } \\
\text { magnet }\end{array}$} & \multicolumn{4}{|c|}{$\begin{array}{c}\text { The thickness of the layer of corrosion } \\
\text { protective coatings }(\mu \mathrm{m})\end{array}$} \\
\hline & $\mathrm{a}$ & $\mathrm{b}$ & $\mathrm{c}$ & $\mathrm{d}(\mathrm{a}+\mathrm{b}+\mathrm{c})$ \\
\hline $\mathrm{V} 2-\mathrm{Z}_{\mathrm{P}}$ & 5.19 & 6.23 & 14.54 & 25.96 \\
\hline $\mathrm{V} 3-\mathrm{V}_{\mathrm{P}}$ & 9.03 & 7.81 & 7.54 & 24.38 \\
\hline
\end{tabular}

\begin{tabular}{|c|c|}
\hline $\begin{array}{c}\text { Representative sample of } \\
\text { magnet }\end{array}$ & $\begin{array}{c}\text { Grain size } \\
(\mu \mathrm{m})\end{array}$ \\
\hline $\mathrm{V} 1-\mathrm{V}_{\mathrm{V}}$ & 8.5 \\
\hline $\mathrm{V} 1-\mathrm{Z}_{\mathrm{V}}$ & 10.6 \\
\hline $\mathrm{V} 2-\mathrm{V}_{\mathrm{V}}$ & 7.2 \\
\hline $\mathrm{V} 2-\mathrm{Z}_{\mathrm{V}}$ & 5.6 \\
\hline $\mathrm{V} 3-\mathrm{V}_{\mathrm{V}}$ & 5.4 \\
\hline $\mathrm{V} 3-\mathrm{Z}_{\mathrm{V}}$ & 6.7 \\
\hline $\mathrm{V} 4-\mathrm{V}_{\mathrm{V}}$ & 9.6 \\
\hline $\mathrm{V} 4-\mathrm{Z}_{\mathrm{V}}$ & 9.3 \\
\hline $\mathrm{V} 5-\mathrm{V}_{\mathrm{V}}$ & 10.9 \\
\hline $\mathrm{V} 5-\mathrm{Z}_{\mathrm{V}}$ & 8.1 \\
\hline $\mathrm{V} 6-\mathrm{V}_{\mathrm{V}}$ & 9.0 \\
\hline $\mathrm{V} 6-\mathrm{Z}_{\mathrm{V}}$ & 6.0 \\
\hline
\end{tabular}

Table $2^{18}$ shows our calculation: the thickness of the individual layers of the corrosion protective coatings and crystal grain size in the magnetic core of the individual samples. Comparison of microstructures and calculated grain sizes in samples from groups of both vibrators and speakers with production years from 2004 to 2007 $\left(\mathrm{V} 4-\mathrm{V}_{\mathrm{V}}, \mathrm{V} 4-\mathrm{Z}_{\mathrm{V}}, \mathrm{V} 3-\mathrm{V}_{\mathrm{V}}, \mathrm{V} 3-\mathrm{Z}_{\mathrm{V}}\right)$ shows that the crystal grains are similar in size and of comparable distribution. Based on this, we can conclude that the magnets of vibrators and speakers are made with a very similar technique of sintering. For the samples with the manufacture dates of 2006, 2008 and $2015\left(\mathrm{~V} 6-\mathrm{V}_{\mathrm{V}}, \mathrm{V} 6-\mathrm{Z}_{\mathrm{V}}\right.$; $\mathrm{V} 2-\mathrm{V}_{\mathrm{V}}, \mathrm{V} 2-\mathrm{Z}_{\mathrm{V}} ; \mathrm{V} 5-\mathrm{V}_{\mathrm{V}}, \mathrm{V} 5-\mathrm{Z}_{\mathrm{V}} ; \mathrm{V} 1-\mathrm{V}_{\mathrm{V}}$ and $\left.\mathrm{V} 1-\mathrm{Z}_{\mathrm{V}}\right)$, we found that the crystal grains are different in size, as well as in microstructure. We can conclude that different techniques of sintering-manufacturing are involved, depending on the intended use of the magnet. In magnet samples of vibrators $\mathrm{V} 2-\mathrm{VV}, \mathrm{V} 4-\mathrm{V}_{\mathrm{V}}, \mathrm{V} 5-\mathrm{V}_{\mathrm{V}}$ and $\mathrm{V} 6-\mathrm{V}_{\mathrm{V}}$, the crystal grains are larger than in magnet samples of speakers $V 2-Z_{V}, V 4-Z_{V}, V 5-Z_{V}, V 6-Z_{V}$. In magnet samples of vibrators $\mathrm{V} 1-\mathrm{V}_{\mathrm{V}}$ and $\mathrm{V} 3-\mathrm{V}_{\mathrm{V}}$ the crystal grains are smaller than in magnet samples of speakers $V 1-Z_{V}$ and $\mathrm{V} 3-\mathrm{Z}_{\mathrm{V}}$.

We expected to get a clear view of the typical topographic details of the analysed magnet samples' surface directly from the SEM microscopy. We deduced from the analysis that the effect of the strong magnetic fields of analysed magnet samples caused distortion, poor resolution, time lag and poor sharpness of surface images. For this reason, the generated images of the
SEM microscopy were not as high-quality as they can be if generated with SEM microscopy of other non-magnetic samples.

\subsection{Microchemical analyses of EDS and WDS \\ WDS Analysis}

In the WDS microchemical analysis of the housing of the vibrator V2-V, the signal at the "peak" site was weaker than the "background" signal. In the analysis process, approximately 800-2000 cts were captured. When testing for the REEs, whose presence we predicted in the housing of the vibrator, the results showed that the REE concentration in the given sample was below the detection limit (the latter was set at 3 sigma above the background). To further confirm the presence of REEs, we performed a spectral scan of the LiF crystal, which is best suited for the REE in the Ce-Lu period of the periodic table. In this area, $\mathrm{Cu}, \mathrm{Ni}$ and $\mathrm{Fe}$, which constitute the main elements of the sample vibrator's housing (Figure 4), also peaked. The findings from the WDS microchemical analysis of the vibrator housing V2-V confirmed the presence of $\mathrm{Cu}, \mathrm{Ni}$ and $\mathrm{Fe}$, as evident from the spectrum and the position of the peaks of these elements (Figure 4). In contrast, the position of the peaks of REE is almost null and void. Based on this, we concluded that the presence of REEs in the analysed housing of the V2-V vibrator is below the detection limit, or the REEs were not present. ${ }^{18}$ Figure 4 shows the
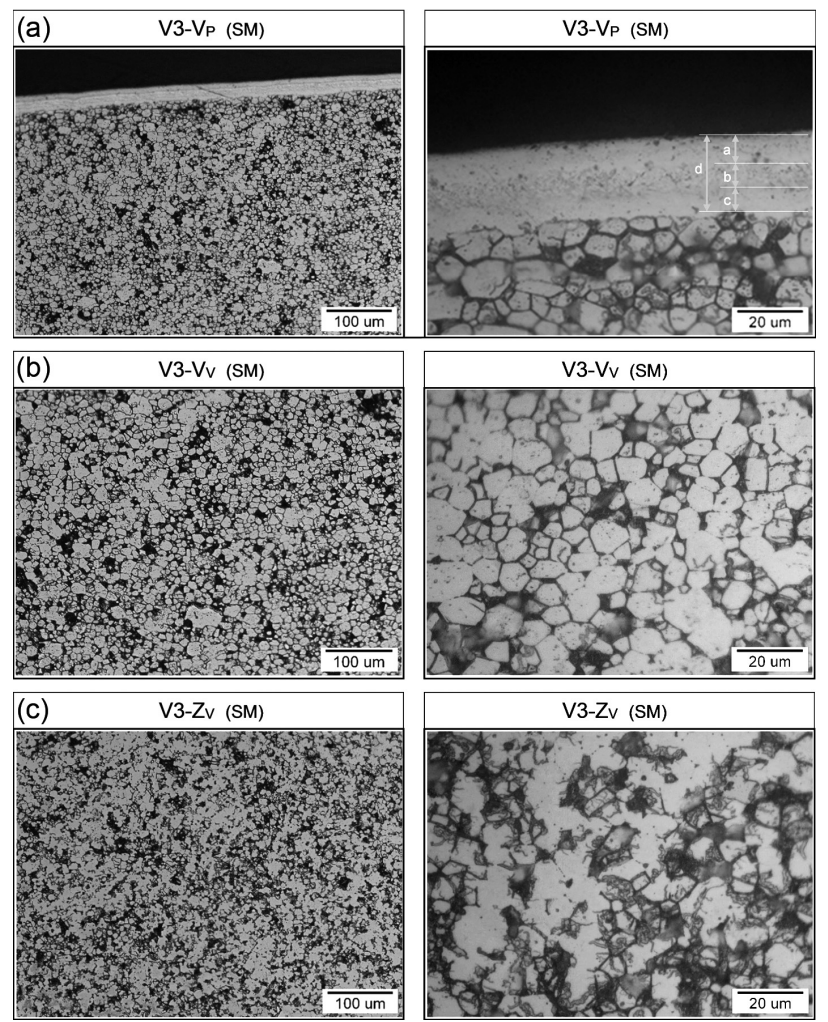

Figure 3: LM microstructure of the surface of samples: a) anticorrosion coating sample $\mathrm{V} 3-\mathrm{V}_{\mathrm{P}}$, b) the magnetic core sample $\mathrm{V} 3-\mathrm{V}_{\mathrm{V}}$, c) the magnetic core sample $\mathrm{V} 3-\mathrm{Z}_{\mathrm{V}}$ 

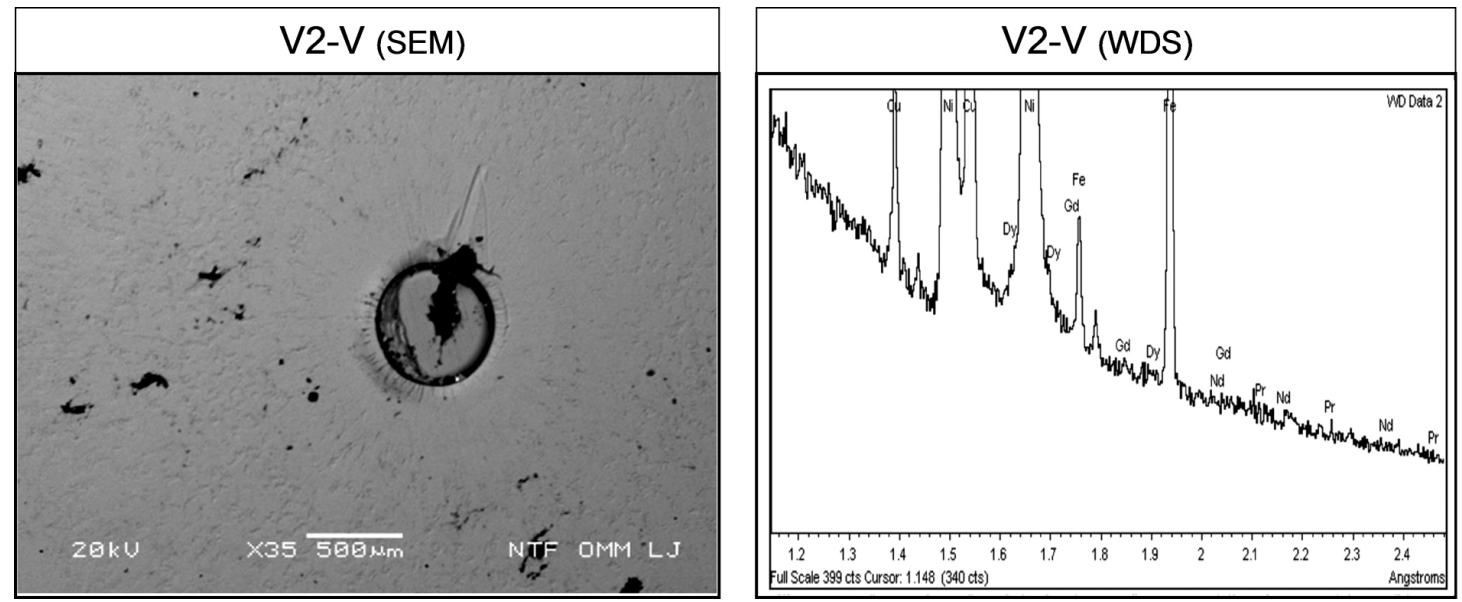

Figure 4: Characteristic WDS spectrum of vibrator housing sample V2-V with the selected place of analysis

mapping of the characteristic spectrum of the analysed vibrator housing sample V2-V in the WDS microchemical analysis, taken at a the lowest speed (for the whole LiF crystal, in this case approximately $4 \mathrm{~h}$ ) with the selected place of analysis.

\section{EDS analysis}

The EDS microchemical analyses of the V2-Vv sample have shown that REEs are not present in the sample, as predicted; the EDS analysis only confirmed the presence of $\mathrm{Cu}, \mathrm{Ni}$ and $\mathrm{Fe}$ (Figure 5). On this basis, we concluded that the magnet sample V2-Vv has anticorrosion protection, as do all the other reference samples of magnets. Next, the layers of the anti-corrosion coating were removed, thus enabling tests directly on the surface of the magnetic cores. These samples were then properly metallographically prepared for further EDS analysis.

In the first stage we performed an EDS analysis of the anti-corrosion coating layers on magnet samples $\mathrm{V} 2-\mathrm{Z}_{\mathrm{P}}$ and $\mathrm{V} 3-\mathrm{V}_{\mathrm{P}}$, and then analysed the distribution of elements in each layer. An example of characteristic EDS spectrums of the anticorrosion coating layers with selected places of analysis and contents of detected elements on the magnet is the typical sample V3- $\mathrm{V}_{\mathrm{P}}$, shown in Figure 6. Microchemical EDS analysis of anticorrosion coating layers of the $\mathrm{V} 2-\mathrm{Z}_{\mathrm{P}}$ sample has shown the presence of $\mathrm{Fe}, \mathrm{Ni}$ and $\mathrm{Cu}$ in layers, namely in the following content:

Place (1): $0.399(w / \%) \mathrm{Fe}, 97.361(w / \%) \mathrm{Ni}$ and 1.970 $(w / \%) \mathrm{Cu}$,

Place (2): $0.355(w / \%) \mathrm{Fe}, 1.640(w / \%) \mathrm{Ni}$ and 98.005 $(w / \%) \mathrm{Cu}$

Place (3): 0.956 (w/\%) Fe, $97.616(w / \%) \mathrm{Ni}$ and 1.419 $(w / \%) \mathrm{Cu}$.

Individual analysis places for the EDS analysis of individual layers (Places (1), (2) and (3)) of the anticorrosion coating have been selected centrally in each layer of the anticorrosion coating. In order to determine the distribution of elements in the layers of the sample V3- $V_{P}$ 's protective coating, EDS "mapping" was conducted (analysis of the distribution of chemical elements on the same surface sample area of the individual anti-corrosion coating layer). Figure 7 illustrates the SEM microstructure of the anticorrosion coating layer on magnet sample $\mathrm{V} 3-\mathrm{V}_{\mathrm{P}}$ with the distribution of the detected elements in those layers. We have determined that the upper layer of the anti-corrosion coating on the
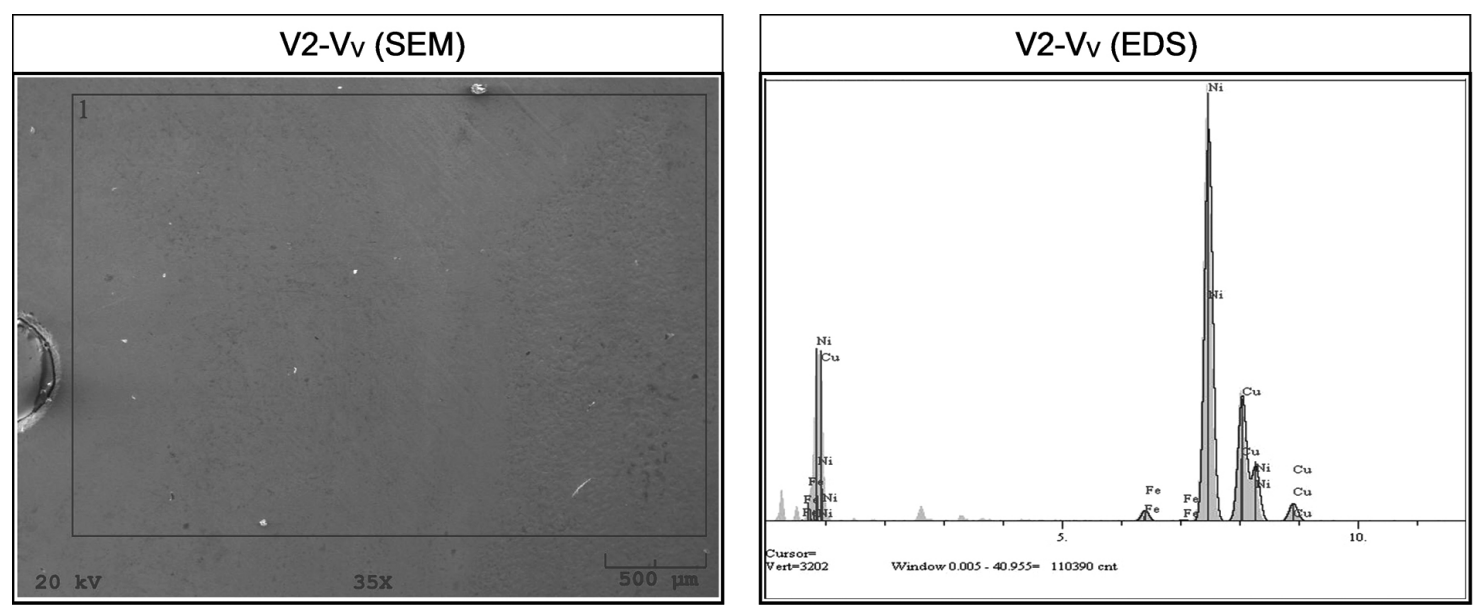

Figure 5: Characteristic EDS spectrum of the sample V2- $\mathrm{V}_{\mathrm{V}}$ with the selected place of analysis (present anticorrosion coating magnetic cores) 
$\mathrm{V} 3-\mathrm{V}_{\mathrm{P}}$ magnet sample of the consists of three singlecomponent layers $(\mathrm{Ni}, \mathrm{Cu}, \mathrm{Ni})$, covering an $\mathrm{Fe}$ magnetic core. The distribution of $\mathrm{Ni}$ in two layers of the surface of the magnet is relatively even, though in certain areas (a few $\mu \mathrm{m}$ in size) the presence of $\mathrm{Ni}$ is significantly diminished. The distribution of $\mathrm{Cu}$ in the layer between the two layers of $\mathrm{Ni}$ is also fairly even; here we also noted certain areas (a few $\mu \mathrm{m}$ in size) with a significantly diminished amount of $\mathrm{Cu}$ present. Further on, we carried out the EDS analysis of representative samples of magnetic cores on samples $V 1-\mathrm{V}_{\mathrm{V}}, \mathrm{V} 1-\mathrm{Z}_{\mathrm{V}}, \mathrm{V} 2-\mathrm{V}_{\mathrm{V}}, \mathrm{V} 2-\mathrm{Z}_{\mathrm{V}}$, V3- $V_{\mathrm{V}}, \mathrm{V} 3-\mathrm{Z}_{\mathrm{V}}, \mathrm{V} 4-\mathrm{V}_{\mathrm{V}}, \mathrm{V} 4-\mathrm{Z}_{\mathrm{V}}, \mathrm{V} 5-\mathrm{V}_{\mathrm{V}}, \mathrm{V} 5-\mathrm{Z}_{\mathrm{V}}, \mathrm{V} 6-\mathrm{V}_{\mathrm{V}}$ and $\mathrm{V} 6-\mathrm{Z}_{\mathrm{V}}$ to determine the presence and content of REEs in the selected samples and the distribution of chemical elements on the surface. An example of characteristic EDS spectrums of the sample vibrator $\mathrm{V} 1-\mathrm{V}_{\mathrm{V}}$ and speaker $\mathrm{V} 1-\mathrm{Z}_{\mathrm{V}}$ 's magnetic cores with selected areas of analysis and contents of the detected elements is shown in Figure 8. The EDS microchemical analysis of samples $\mathrm{V} 1-\mathrm{V}_{\mathrm{V}}$ and $\mathrm{V} 1-\mathrm{Z}_{\mathrm{V}}$ revealed presence of REEs as follows:

Sample V1-V $12.005(w / \%)$ Pr, $8.094(w / \%) \mathrm{Nd}$ and $7.130(w / \%) \mathrm{Gd}$,

Sample V1-Zv: $2.437(w / \%)$ Pr, $9.953(w / \%)$ Nd and $1.179(w / \%) \mathrm{Gd}$.

The comparison of the results exhibited the highest number of different REEs in samples $\mathrm{V} 1-\mathrm{V}_{\mathrm{V}}$ and $\mathrm{V} 1-\mathrm{Z}_{\mathrm{V}}$. In addition to $\mathrm{Nd}$ and $\mathrm{Pr}$, which also separately occur in other samples, Gd has been identified in the aforementioned samples $\left(\mathrm{V} 1-\mathrm{V}_{\mathrm{V}}\right.$ and $\left.\mathrm{V} 1-\mathrm{Z}_{\mathrm{V}}\right)$. In order to determine how the REEs are distributed on the selected surface of the magnetic core, EDS "mapping"/analysis of the distribution of chemical elements was performed in the same area of the sample magnet V1- $\mathrm{V}_{\mathrm{V}}$. EDS "mapp-
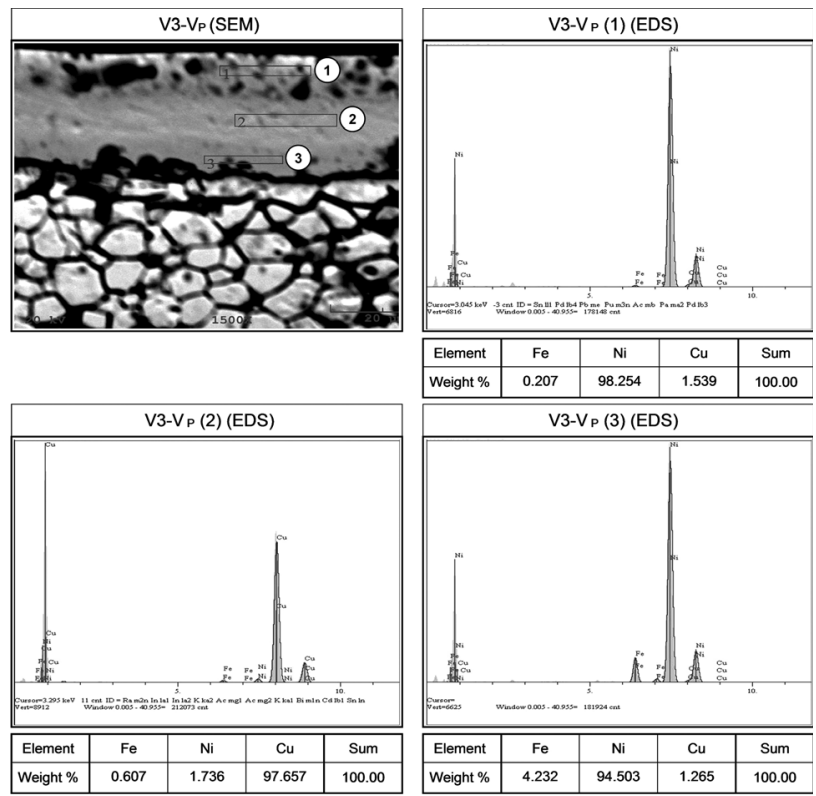

Figure 6: EDS characteristic spectrum of layers of anticorrosion coating in sample $\mathrm{V} 3-\mathrm{V}_{\mathrm{P}}$ with selected places of analysis and contents of the detected elements $(w / \%)$ ing" (Figure 9) shows a relatively even distribution of the elements $\mathrm{Fe}, \mathrm{Pr}, \mathrm{Nd}$ and $\mathrm{Gd}$, and certain areas (a few $\mu \mathrm{m}$ in size) partly certain areas with a significantly diminished amount of the above elements (Fe, Pr, Nd and $\mathrm{Gd}$ ) are visible. An overview of the REE content in other representative magnet samples without the protective anti-corrosion layer is given in Table 3. ${ }^{17}$

Table 3: The levels in the samples ERZ magnets ( $w / \%)$

\begin{tabular}{|c|c|c|c|}
\hline \multirow{2}{*}{$\begin{array}{c}\text { Representative } \\
\text { sample of } \\
\text { magnet }\end{array}$} & \multicolumn{3}{|c|}{ The levels of detected rare earth elements } \\
\cline { 2 - 4 }$(w / \%)$
\end{tabular}

By means of the EDS microchemical analysis of the magnetic core samples without the corrosion protective layers, except for sample $\mathrm{V} 2-\mathrm{V}_{\mathrm{V}}$ (significantly lower content of Pr), we found that, regardless of the mobile phone's production year, there is no major discrepancy in the content of REEs Pr and Nd (Table 3). Discrepancy occurred only in samples $\mathrm{V} 1-\mathrm{V}_{\mathrm{V}}$ and $\mathrm{V} 1-\mathrm{Z}_{\mathrm{V}}$, where $\mathrm{Gd}$ was additionally identified (year 2015). We assume that this is due to the development of magnet manufacturing technology (new chemical composition and higher requirements regarding the functional properties of the magnets). As for the vibrator samples V3- $\mathrm{V}_{\mathrm{V}}$ (year 2007) and V4- $\mathrm{V}_{\mathrm{V}}$ (year 2004), we detected the same REE
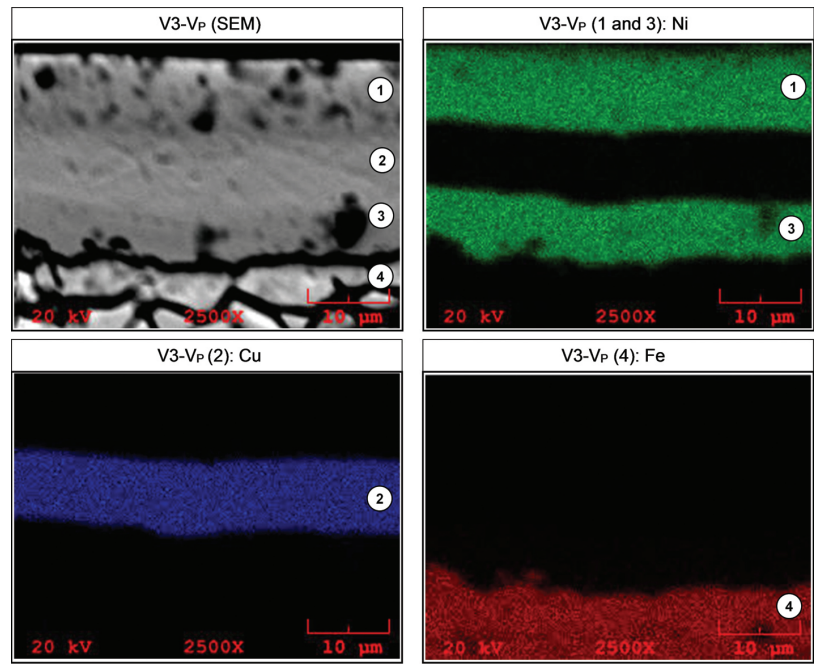

Figure 7: SEM microstructure layers of anticorrosion coating sample in $\mathrm{V} 3-\mathrm{V}_{\mathrm{P}}$ with the distribution of the detected elements in those layers 


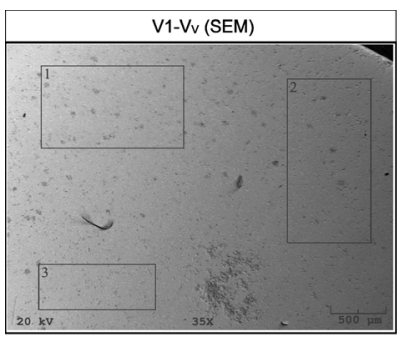

a)

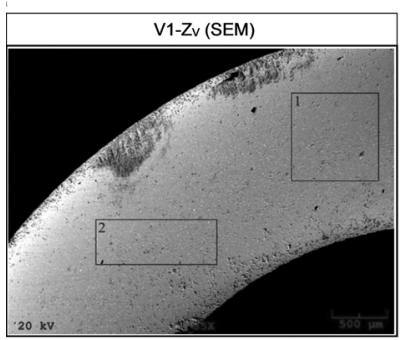

b)
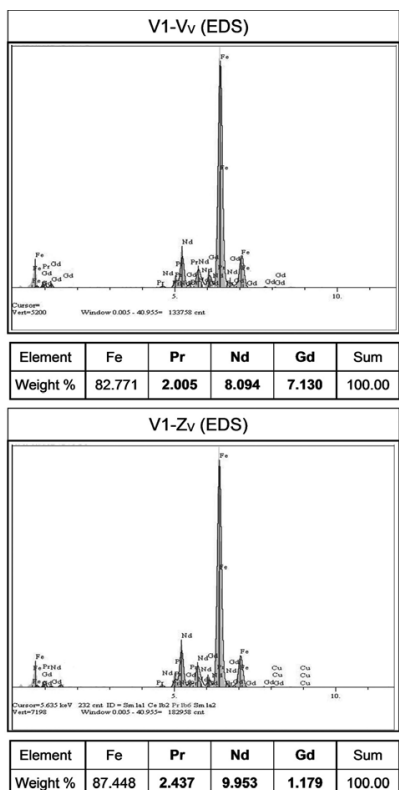

Figure 8: Overview of characteristic EDS spectra of samples from selected places of analyses, contents of the detected elements $(w / \%)$ : a) the pattern $\mathrm{V} 1-\mathrm{V}_{\mathrm{V}}$ and $\mathrm{b}$ ) the pattern $\mathrm{V} 1-\mathrm{ZV}_{\mathrm{V}}$

content (in mass fractions, $(w / \%)(\mathrm{Pr}, \mathrm{Nd}))$ despite different production years of the mobile phones. We conclude that this is due to the same magnet manufacturer. ${ }^{17}$

\section{CONCLUSIONS}

Using Light and Electron Microscopy, we evaluated the microstructure of mobile phone components containing REE. By using microchemical analysis methods, we determined the proportion of REEs. Our conclusions are as follows:

- Mobile phones are made of several components, of which only the vibrator and the speaker contain sufficient amounts of REEs usable for recycling.

- The examined magnets of the vibrator and speaker are located in the housings. They consist of a anticorrosion coating and the core.

- Microchemical WDS and EDS analyses of the vibrator and speaker housing did not confirm the presence of REE.

- Anti-corrosion coating of magnets is composed of three layers $(\mathrm{Ni}-\mathrm{Cu}-\mathrm{Ni})$. Its thickness ranges from $24 \mu \mathrm{m}$ to $26 \mu \mathrm{m}$, the outer layer being $\mathrm{Ni}$.

- The microstructure of magnetic cores we examined is typical for sintered materials. The estimated size of the rudimental crystal grains in the magnetic core is from $5.4 \mu \mathrm{m}$ to $10.9 \mu \mathrm{m}$ depending on the model and production year of the mobile phone.

- The magnetic core is composed of Fe-Nd-Pr and enriched with Gd in the newer mobile phones.

- WDS and EDS microchemical analysis, together with REE and Fe distribution on the selected surface, point
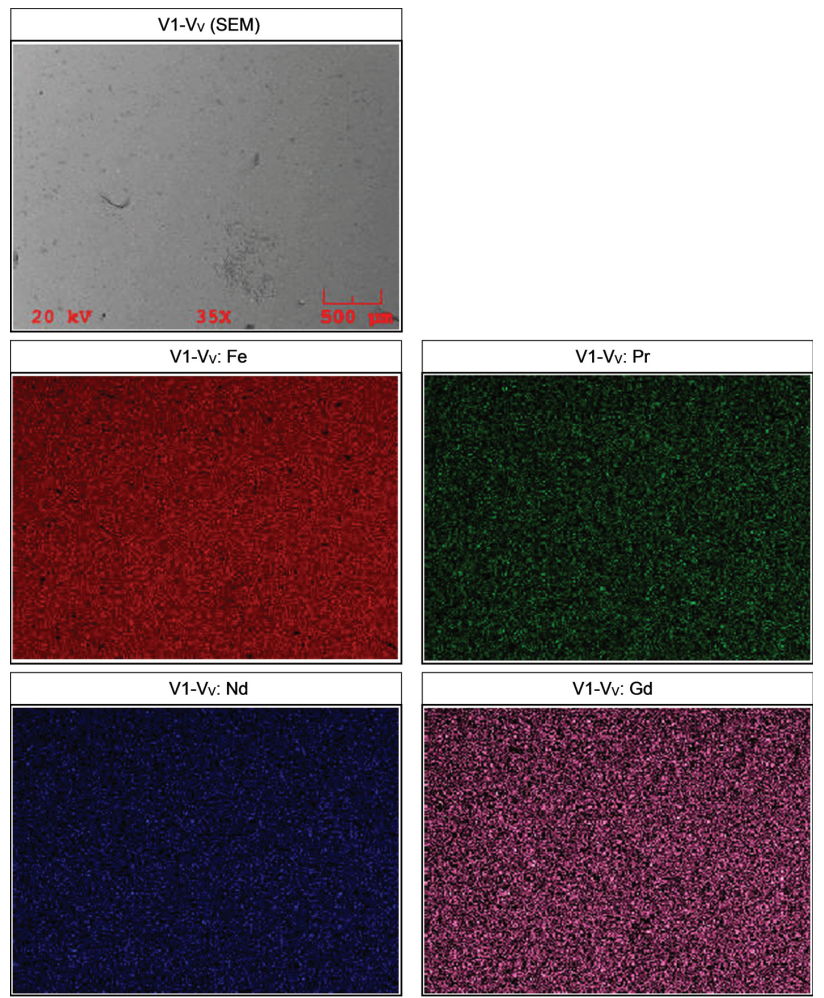

Figure 9: Overview of SEM microstructure of the magnetic core sample $\mathrm{V} 1-\mathrm{V}_{\mathrm{V}}$ with the distribution of the detected elements on the surface

to the fact that the magnetic core is homogenous in volume in its chemical composition.

- The conduct of the microchemical analysis was disrupted due to the impact of the magnetic REEs. This resulted in distortion and reduced resolution of the electronic image. Magnetic impact on the EDS microchemical analysis was negligible.

- The two main magnets (vibrator and speaker) in an individual mobile phone have a REE content of $13.5 \%(w / \%)$, representing a combined estimated weight of $0.082 \mathrm{~g}$.

- The chosen characterization methods (LM and SEM microscopy) in combination with microchemical EDS and WDS analysis, are relevant for determining the presence and content of REEs in magnets of disused mobile phones.

Provided that all parties (manufacturers, dealers, users, processors, etc.) included in the life cycle of mobile phones are made aware of the correct sorting and collecting principles, specified by the European Directive on WEEE (which among others include a $45 \%$ collection quota of WEE, including mobile phones, an $80 \%$ processing quota and a $70 \%$ recycling quota between the years 2015 and 2018) and taking into account the 210.3 million mobile phones released on the European market in 2015 alone, it is theoretically possible that by using modern recycling technologies and procedures we could extract up to $476,960 \mathrm{~kg}$ of copper, $13,249 \mathrm{~kg}$ of silver $1,272 \mathrm{~kg}$ of gold and $477 \mathrm{~kg}$ of 
palladium. Considering the findings of the present study, that show the average REE content in the speaker and vibrator of a mobile phone is approximately $13.5(\mathrm{w} / \%)$ and the total estimated REE weight is $0.082 \mathrm{~g}$, we could, in theory, by using modern recycling procedures, extract $4,345 \mathrm{~kg}$, disregarding the amounts of REE found in other functional mobile phone components (circuit, microphone, display and camera)..$^{18}$

As for the economic and sustainability aspect of the recycling process and its justifiability, an additional uptrend is expected from 2019 onwards. For this period, the European Directive on WEEE foresees a $65 \%$ collection, $75 \%$ processing and $55 \%$ reusability and recycling quota of the estimated more than 250 million mobile phones being released on the market in 2018..$^{13,18}$

Based on the reviewed scientific literature, other studies on the topic and the analyses and results of our own research work, we can conclude that laboratories and special chemical procedures for REE extraction are required for the recycling of discarded mobile phones. As a consequence, incidental costs arise, which are disproportionate to the quantity of recovered REEs and their economic value. Furthermore, REEs are not the only valuable material usable for recycling and reuse. We must strive towards acquiring other secondary raw material, including copper, silver gold and palladium, in addition to REEs in the recycling process., ${ }^{9,20}$ Thus, we can deduce that the recycling REEs from the components of discarded mobile phones is economically justifiable as long as we also recover valuable secondary raw material $(\mathrm{Cu}, \mathrm{Ag}, \mathrm{Au}, \mathrm{Pd}, \mathrm{Pt}$, etc.) in the process.

In addition to the economic aspect of recycling discarded mobile phones, we must take into consideration the sustainability aspect of the matter, from which recycling discarded mobile phones is well-justified and crucial. Moreover, we must take into account that the quantity of recovered REEs and other valuable raw material is not the only positive effect. By recycling discarded mobile phones, we also make a critical contribution to reducing the unregulated accumulation of WEE and to improving the resource efficiency, help regulate the quantity of REEs on the market, assist the recovery of valuable secondary raw material, and lastly considerably reduce negative effects on the environment, to which we are bound by the European Directive on WEEE. ${ }^{18,20}$

\section{Acknowledgements}

We would first like to extend our thanks to the Slovenian Research Agency (ARRS), whose co-funding enabled the research conducted within the framework of the Research Project (no. L2-5486) and Core Programme P2-120 and Ministry of Education, Science and Sport, Republic of Slovenia (Programme MARTINA, OP20.00369). We would also like to thank the management and the technical assistance staff at the Department of Materials and Metallurgy of the Faculty of Natural
Sciences of the University of Ljubljana, as well as those at the University Centre for Electron Microscopy Maribor (UCEM), the Institute of Metals and Technology (IMT) and the Faculty of Mechanical Engineering in Maribor for enabling the research and providing expertise. Last but not least, we would like to thank the the Academic and Scientific Union of Pomurje (PAZU).

\section{REFERENCES}

${ }^{1}$ M. Drofelnik, General and Anorganic Chemistry, $3^{\text {rd }}$ revised ed. UM, Faculty of Chemistry and Chemical Technology, Maribor, 2013, 289-293

${ }^{2}$ Chemie.de, http://www.chemie.de/lexikon, 22.02.2016

${ }^{3}$ Rare Earth Elements. BGS, Minerals UK, 2011. http://www.bgs. ac.uk/mineralsUK/statistics/mineralProfiles.html, 18.02.2016

${ }^{4}$ M. Štamulak, The Battle for Rare Earth Elements, Cresus, 2011, http://www.cresus.si/boj-za-redke-zemlje/,15.04.2016

${ }^{5}$ R. J. Weber, D. J. Reisman: Rare Earth Elements: A Review of Production, Processing, Recycling, and Associated Environmental Issues. EPA, U.S. Environmental Protection Agency, 2012, https://www.epa.gov/research in http://nepis.epa.gov/Adobe/PDF/ P100EUBC.pdf/, 19.04.2016

${ }^{6}$ M. Russell: What are rare earth metals? Mother Nature Network, 2011. http://www.mnn.com/earth-matters/translating-uncle-sam/ stories/what-are-rare-earth-metals, 16.04.2016

${ }^{7}$ What are Rare Earth Elements? EUrare, http://www.eurare.eu, 19.04.2016

${ }^{8}$ M. Smodiš, N. Samec, Č. Donik, B. Kosec, R. Rudolf, Analysis of rare earth elements in mobile phones, IRT 3000, 63 (2016), 162-165

${ }^{9}$ Strengthening of the European Rare Earths Supply Chain : Challenges and policy options. EU Commission GROWTH, 2015, http://ec.europa.eu/growth/sectors/ rawmaterials/specificinterest/ erecon/index_en.htm, 16.04.2016

${ }^{10}$ G. Barakos, H. Mischo, J. Gutzmer, An outlook on the rare earth elements mining industry, The Australasian Institute of Mining and Metallurgy, https://www.ausimmbulletin.com/feature/an-outlookon-the-rare-earth-elements-mining-industry/, 12.02.2016

${ }^{11}$ A Quick Glance at WEEE Statistics: USA, China, Africa. European Recycling Platform (ERP), 2015, http://erp-recycling.org/news/aquick-glance-at-weee-statistics-usa-china-africa/, 05.03.2016

${ }^{12}$ Waste statistics - electrical and electronic equipment. EU Commission, Eurostat, 2016, http://ec.europa.eu/eurostat/statistics-explained/ index.php/Waste_statistics-electrical_and_electronic_equipment/, 17.02.2016

${ }^{13}$ Directive 2012/19/EU of the European Parliament and of the Council of 4 July 2012 on waste electrical and electronic equipment (WEEE). Official Journal of the European Union, L197/38, 2012, http://eurlex.europa.eu/legalcontent /SL/TXT/PDF/?uri=CELEX: 32012L0019\&from=N/, 08.04.2016

${ }^{14}$ P. Gramatyka, R. Nowosielski, P. Sakiewicz, Recycling of waste electrical and electronic equipment, Journal of Achievements in Materials and Manufacturing Engineering, 20 (2007)1-2, 535-538

${ }^{15}$ In-depth - Mobile Phones, Ellen MacArthur Foundation. http://www.ellenmacarthurfoundation.org/circulareconomy/interactiv ediagram/in-depth-mobile-phones/, 19.04.2016

${ }^{16}$ Gartner Says Global Smartphone Sales to Only Grow 7 Per Cent in 2016. Gartner, Inc., 2016. http://www.gartner.com/newsroom/id/ 3270418/, 13.04.2016

${ }^{17}$ Report on critical raw materials for the EU: Report of the Ad-hoc Working Group on definingcritical raw materials. European commission, 2014. http://ec.europa.eu/docsroom/documents/10010/ attachments/1/translations/en/rendition/native, 23.04.2016

${ }^{18}$ M. Smodiš, Raziskava vsebnosti elementov redkih zemelj v prenosnih telefonih, master's thesis, UM, Faculty of Mechanical Engineering, Maribor, 2016 
M. SMODIŠ et al.: THE CONTENT OF RARE-EARTH ELEMENTS IN MOBILE-PHONE COMPONENTS

${ }^{19}$ S. Spaić, Metallographic analysis, UL, Faculty of Natural Sciences and Engineering, Department of Mining and Geotechnology, Ljubljana, 1993, 141-155

${ }^{20}$ K. Binnemans, P. T. Jones, B. Blanpain, T. V. Gerven. Y. Yang, A.

Walton, M. Buchert. Recycling of rare earths: a critical review. Journal of Cleaner Production 51 (2013) 1-22, https://solvomet.eu/ wpcontent/uploads/2017/05/JCLEPRO_Binnemans_REE_Recycling_May2013.pdf, 15.09.2017 